\title{
Lumen
}

Selected Proceedings from the Canadian Society for Eighteenth-Century Studies

\section{“A Constellation of Scottish Genius”: Networks of Exchange in Late 18th- and early 19th-Century Edinburgh}

\section{Pam Perkins}

Volume 34, 2015

URI : https://id.erudit.org/iderudit/1028510ar

DOI : https://doi.org/10.7202/1028510ar

Aller au sommaire du numéro

Éditeur(s)

Canadian Society for Eighteenth-Century Studies / Société canadienne d'étude du dix-huitième siècle

ISSN

1209-3696 (imprimé)

1927-8284 (numérique)

Découvrir la revue

Citer cet article

Perkins, P. (2015). “A Constellation of Scottish Genius”: Networks of Exchange in Late 18th- and early 19th-Century Edinburgh. Lumen, 34, 39-54.

https://doi.org/10.7202/1028510ar 


\title{
"A Constellation of Scottish Genius": Networks of Exchange in Late 18th- and early 19th-Century Edinburgh
}

\author{
Pam Perkins
}

University of Manitoba

In 1810, the critic Francis Jeffrey published a major Edinburgh Review article on the lives and literary work of Madame du Deffand and Julie de Lespinasse in which, while offering a thoughtful and sympathetic reading of salon culture, he nonetheless made clear that he saw such modes of literary sociability as being completely at odds with British cultural practices. According to him, the reason that Frenchwomen's drawing rooms had been and remained "better filled than ours, [...] and their conversation $[\ldots]$ more sprightly, and their society more animated" is that Frenchmen have "no other outlet for [their] talent and ingenuity [...] but society and conversation." As he goes on to explain, the most able men in Britain, in marked contrast to their French counterparts, are preoccupied with their professional lives, leaving sociable gatherings to the idle and the foolish. Jeffrey's rather glib national stereotypes might not sit well with twentieth- and twentyfirst century criticism, but a number of recent critics have echoed the other part of his argument, suggesting that late eighteenth-century Britain in general, and Edinburgh in particular, saw a shift away from an older practice of feminised literary sociability and towards an idea of literary pursuits as part of a masculine, professional world. In particular, as Clifford Siskin argued in the late 1990s, The Edinburgh Review itself, with its vigorous discussion of the arts and sciences,

1. Francis Jeffrey, "Madame du Deffand and Mademoiselle de Lespinasse" in The Edinburgh Review 15 (1810): 461. 
offered a print, professionalised version of what David Hume had called the "conversable world" of the salons-and in doing so, as Siskin suggests, diminished the importance of the social networks that had allowed at least some women to exert significant literary influence. ${ }^{2}$ Yet much of the contemporary commentary on early nineteenth-century Edinburgh, by both residents and visitors, suggests that far from being superseded by new modes of literary production, sociable exchange remained a key aspect of the city's literary culture. These many accounts of the continuing impact of Edinburgh's literary networks quickly erode any clear, clean division between the masculine, the professional, and the literary worlds on the one hand and the feminine, the domestic, and the sociable on the other and, in the process, disrupt any supposedly smooth trajectory from salon to magazine, from conversation to print, and from feminine to masculine literary work. Even as Jeffrey and the other writers for the Edinburgh periodicals and popular press helped to establish a new model of professional authorship, they in fact remained steeped in the practices of literary sociability and coterie authorship.

Of course, informal manuscript exchange among friends or within loose coteries is very different from the sort of formal salon culture that Jeffrey was writing about. That said, the salon and the coterie can be at least tenuously linked as elements within a concept of intellectual work that embraces the privacy and ephemerality of scribal or even oral circulation. As critics have begun paying more attention to the various ways that eighteenth-century writers shared or disseminated their work, the version of literary history that sees the era as marking a relatively smooth progression towards a print-based, professional model of authorship, and away from more sociable modes of literary production, has been subject to an increasing number of challenges. In particular, critics of eighteenth- and nineteenth-century literature have been documenting the survival and transformation of types of literary production that are more generally associated with earlier periods. Betty Schellenberg, for example, traces the continuing impact of coterie authorship-a practice more usually associated with the seventeenth

2. Clifford Siskin, The Work of Writing: Literature and Social Change in Britain, 1700-1830 (Baltimore: Johns Hopkins University Press 1998), 218-24. Ian Duncan also comments on this cultural shift in his important study Scott's Shadow: The Novel in Romantic Edinburgh (Princeton: Princeton UP, 2007); see especially $25-26$ and $42-45$. 
century -into the last decades of the eighteenth. Schellenberg's helpful working definition of the coterie makes clear the flexibility that it continued to offer writers who, for whatever reason, chose to circulate their work by means other than print; a coterie, in her words, was a

group of individuals, bound together by a variety of overlapping social ties-kinship, geography, clientage relationships, friendship-whose personal interactions prominently featured literary exchanges, including the circulation of original compositions by members of the group, revision of those compositions, and critical commentary on them. ${ }^{3}$

Nor does social authorship necessarily imply a complete avoidance of print. As critics including Michelle Levy, Kathryn Ready, and Julia Wright ${ }^{4}$ have demonstrated in their studies of eighteenth- and nineteenth-century family coteries-the Aikens, the Edgeworths, and the Lefanus, among others-an author might choose, even well into the nineteenth century, to move back and forth between print and social circulation of her work. Indeed, as Jon Mee has recently argued, from the mid-eighteenth century until well into the nineteenth, "conversation could function as a source of authority" for writers who chose to publish, especially relative outsiders such as women or those based in the provinces. 5

This criticism complicates what has been the tendency, until recently, to see print as replacing modes of social authorship, rather than complementing them. To quote Schellenberg again, "[t]he persistence

3. Betty Schellenberg, "Coterie Culture, the Print Trade, and the Emergence of the Lakes Tour, 1724-1787," Eighteenth-Century Studies 44:2 (2011), 205. Margaret J. M. Ezell's Social Authorship and the Advent of Print (Baltimore: Johns Hopkins UP, 1999) offers what is still one of the fullest analyses of modes of social authorship in the seventeenth-century context, although unlike Schellenberg and other recent critics building on Ezell's work, Ezell herself sees the various forms of social authorship as declining with the increasingly firm establishment of print over the course of the eighteenth century.

4. See, for example, Michelle Levy, Family Authorship and Romantic Print Culture (New York: Palgrave Macmillan, 2008); Kathryn Ready, "Dissenting Sociability and the Anglo-American Context: The Correspondence of William Ellery Channing and Lucy Aikin," Symbiosis: A Journal of Anglo-American Literary Relations 9.2 (2005): 117-33; and Julia Wright, "At the Fire-Side Circle: Irish Women Writers and the Sheridan-Lefanu Coterie," Keats-Shelley Journal: Keats, Shelley, Byron, Hunt and their Circles 55 (2006): 63-72.

5. Jon Mee, Conversable Worlds: Literature, Contention, and Community 17621830 (Oxford: Oxford UP, 2011), 115. 
of manuscript culture in eighteenth-century Britain has been difficult to recognize because of the generally accepted view that this period marks [...] an overwhelming and definitive shift to print." ${ }^{\text {"T }}$ The continuing impact of modes of social authorship might be all the more likely to be overlooked in the case of early nineteenth-century Edinburgh because of the city's major and, in the short term, remarkably successful innovations in the literary marketplace. As Ian Duncan has argued in his influential reassessment of Romantic-era Scottish fiction, Scotland at this time witnessed "the commercial devolution of the Scottish Republic of Letters," in part through "a displacement of Enlightenment cultural formations into "the press'” While Duncan notes that the literary culture of Edinburgh at the turn of the century included an "uneven combination of 'modern' and 'traditional' elements," his focus is naturally directed towards the practices fuelling the cultural shift he is analysing. ${ }^{7}$

Yet there are several reasons that the "persistence" of at least one of those "traditional elements" - the various forms of social authorshipalso merits attention. First, recognizing the continuing importance of non-print modes of literary production opens the way to a re-evaluation of the role that women played in Edinburgh culture. After all, the realm of social authorship is one that has always been accepted as being more accessible to female writers than were nineteenth-century versions of literary professionalism. Even though a few early nineteenth-century women could (and did) build themselves what were, in effect, professional careers, access to what Clifford Siskin calls "the professional criterion of earned expertise" was closed to them. ${ }^{8}$ Yet it was possible to be a respected participant in Edinburgh's literary world without being a "professional" in the sense that Siskin sketches out, despite the often unspoken assumption that by the later eighteenth century a writer's decision to circulate in manuscript is a mark of amateurism, of a failure of nerve, or, at best, of a cautious attempt to test the market. There is no doubt that some writers did circulate their work privately and then used the audience that they had built as the basis of a launch into print: the Scottish poet and letter writer Anne

6. Schellenberg, 205 .

7. Duncan, 24-26.

8. Siskin, 222. 
Grant was able to build a very large subscription list for the volume of poems she published in 1803 in part because over the previous decades she had created a coterie readership for herself. Yet any attempt to read Grant's career as a decisive move away from the amateur world of manuscript circulation and into print and literary professionalism quickly founders in the details of her writing life. For one thing, she continued to collect and circulate works in manuscript long after becoming a published author. No less importantly, as one of the major literary hostesses of early nineteenth-century Edinburgh, she exercised her literary influence as much through her social gatherings as through her publications. Even if, in terms of literary history, it is more difficult to assess Grant's contributions as a hostess, a letter writer, and an informal, generally unpublished critic than it is to evaluate her books, the fact that she was able to use both print and social authorship to create a position of some literary influence for herself demonstrates the difficulty of maintaining any absolute division between the worlds of "professional" print authorship and literary sociability in Edinburgh at this time.

This difficulty becomes even more vexing in the case of Grant's contemporary and friend, Eliza Fletcher. In the opening decades of the nineteenth century, Fletcher was one of the most glamourous of Edinburgh's literary celebrities, so much so that she attracted transatlantic interest. A young American poet who visited Edinburgh in 1825 was disappointed to find that his arrival during the vacation meant that he was unable to meet a number of the city's prominent literary figures: Fletcher, along with Sir Walter Scott, was one of the two people whose absence he particularly regretted. ${ }^{9}$ A few years earlier, another young American, George Ticknor, had been more successful in his attempt to obtain introductions to both Anne Grant and Eliza Fletcher, and he thought the meetings sufficiently important to send detailed accounts of them back home. Noting that Fletcher's "conversation is more sought than that of anybody" else in the city, Ticknor also gives a measure of her contemporary fame by reporting that Henry Brougham, already well-launched on his political career, had tried fruitlessly to

9. Nathaniel Hazeltine Carter, Letters from Europe. 2 vols. (New York: G. \& C. Carvill, 1827), 1: 245 . 
persuade her to move to London so that he could more frequently enjoy her company and conversation. ${ }^{10}$

What is remarkable about Fletcher's literary reputation is not just its extent but also the fact that it was based strictly on her sociable and private exchanges. (In contrast, Grant was the author of a book about life in pre-Revolutionary America and so had established a transatlantic readership.) Aside from a privately-printed verse drama, circulated only to a few friends, Fletcher published nothing during her lifetime. Elizabeth Isabella Spence, a novelist and travel writer who visited Edinburgh in 1816, attempted to explain Fletcher's influence by describing her as "the Mrs. Montague [sic] of Edinburgh," thereby slotting her into an established Enlightenment pattern of female literary work. ${ }^{11}$ Yet the comparison, however superficially flattering to Fletcher, does not quite work, as it can be difficult to map the sort of literary sociability practiced by Fletcher onto the more familiar role of even the anglicised version of the Enlightenment salonière. Montagu, after all, was a published writer as well as the hostess of a salon, and so her place then and now in a literary world that valorizes print remains more easily explicable. While the fact that Fletcher has faded almost completely from literary history might indicate the importance of print authorship in our present understanding of what constitutes literary work, her contemporary reputation suggests that any division between the authority of print and the cultural power granted by certain forms of sociability remained blurred, in at least some respects, in the Edinburgh literary world until well into the nineteenth century.

By 1801, for example, without having published a word, Fletcher had built enough of a reputation for literary judgment for the scholar, biographer and editor Robert Anderson to consult her about a manuscript treatise on female education that he had received. Fletcher's initial polite protests that she lacked the requisite professional expertise are clearly a matter of form: after briskly moving through the conventional self-deprecation, she goes on to provide a withering critique of the book itself, which, whether because of Fletcher's opinion or not, was never published. Fletcher apparently did not know anything

10. George Ticknor, Life, Letters and Journals. 2 vols. (Boston: James R. Osgood \& Company, 1876), 1: 278-79.

11. Elizabeth Isabella Spence, Letters from the North Highlands during the Summer 1816. (London: Longman, 1817), 36. 
about the author, a Dumfriesshire schoolmaster and educational writer named William Mackenzie, but he knew who she was. While understandably defensive in his response to the critique, he nonetheless proclaimed himself deeply gratified by the "honour" Fletcher "ha[d] done [him] in perusing [his] production." ${ }^{2}$ However conventional the language, the fact that Mackenzie felt obliged to declare that he took even a negative critique from "Mrs. F." as a favour and an honour is an indication that she had a degree of real power in the public literary world that he aspired to join.

Nor was Anderson the only person in Fletcher's circle to seek out her opinions on literature in which he had a professional interest. The antiquarian, engraver and editor Robert Hartley Cromek turned to her for information on traditional Scottish ballad culture, asking her to verify Jean Adam's authorship of the song "There's nae Luck About the House"; Fletcher responded both through correspondence with Adam's granddaughter and through a detailed, judicious evaluation of the evidence provided. In addition, by providing Cromek with an introduction to the family of the Nithsdale poet Allan Cunningham, she helped him in his work on Nithsdale and Galloway Song. ${ }^{13}$ It is perhaps a measure of her literary tact that Fletcher followed up the introduction by warning Cromek that Cunningham's weakness as a poet was too great an "admiration of ancient ballads," an admiration that Cunningham later demonstrated by writing almost all of the supposedly "traditional" songs he provided for Cromek's book. Nor was that the end of Fletcher's involvement with the project; when Cunningham decided to go public with that story some years later, she also advised him on how he might best bring his account into print.

That said, Fletcher did not just provide advice, criticism, and introductions; she also wrote and circulated some of her own work. Cunningham described Fletcher as a "poetess" when he mentioned her in the introduction to his published Poems and Songs, and even if there is a hint of condescension in his use of the feminised form of the word, it demonstrates that the manuscript exchange between the two

12. William Mackenzie, unpublished letter to Robert Anderson, 9 November 1801, Edinburgh: National Library of Scotland, ADV.MS. 22.4.11, f.44

13. Eliza Fletcher, unpublished letter to Robert Hartley Cromek, 25 January 1810. Edinburgh: National Library of Scotland, MS 2617, ff. 65-66. The lines quoted below about Cunningham appear in the same letter. 
went both ways. She also sent her privately printed Dramatic Sketches to a number of those among her friends who had established themselves in the world of print authorship and clearly both expected and enjoyed the responses that she received. When Robert Anderson was slow in replying with his comments, Archibald Fletcher wrote to express his surprise that neither he nor his wife had yet "heard" from Anderson "on the subject." Anderson took the hint: a little over two weeks later Archibald Fletcher was writing again to say how "exceedingly gratified" his wife was by Anderson's "critical examination" of her "little volume." Again, it might initially appear tempting to read this decision to circulate only to friends as a conventionally feminine nervousness about print; that is, after all, the way that Archibald Fletcher framed the matter when he told Anderson that his wife could not "prevail upon herself" to publish. ${ }^{14}$ Yet Eliza Fletcher herself later commented to one of her daughters that the private admiration that she received from distinguished published writers-Anderson, Archibald Alison, Joanna Baillie, and Lucy Aikin, among others-was a "flattering unction" that gave her far more satisfaction that she could ever find by risking "a good trimming" from some "scornful, contemptuous reviewer."15 In other words, coterie authorship offered her more gratification and satisfied her ambition more fully than publication could. Readers today might find that conclusion a little disingenuous, but Fletcher was not the only member of her circle to use that sort of rhetoric. Only a few months earlier, Thomas Campbell had proclaimed in a letter to Fletcher that The Quarterly Review's attack on his poem Theodoric was an "injustice" that he felt all the more strongly because knowing that he had "touched [her] intellectual heart" made it impossible for him to accept that a "heartless reviewer" should "say uncontradicted that the work is uninteresting."

Whatever Fletcher's reasons for choosing never to pursue wide public recognition as an author, the range of her literary connections and friendships make clear that even without moving into print, she

14. Archibald Fletcher, unpublished letters to Robert Anderson, 21 November and 9 December 1825, Edinburgh: National Library of Scotland, ADV.MS. 22.4.11, ff. $246,248-49$.

15. Mary Richardson, ed. Autobiography of Mrs. Fletcher (Edinburgh: Constable, 1875), 177 .

16. Richardson, 178. 
was able to build and maintain a literary career that won her both praise as a writer and influence as a reader. Indeed, Campbell suggested that his best recourse against the Quarterly would not be a more positive published review (Jeffrey had in fact provided one, but Campbell dismissed it on the grounds that Jeffrey did not really understand the poem); rather, he hoped that Fletcher would be willing to "give[ ] publicity to [her] literary opinion" of it. Whether or not she helped Campbell in this case, she was ready to do favours of that sort for those among her literary circle who did choose to publish. After Allan Cunningham had secured a place at London's Literary Gazette, for example, she sent him a copy of a poem by her acquaintance Catherine Grace Godwin, telling him bluntly that he would "oblige her extremely" if he were willing to "make honourable mention" of it in the journal. ${ }^{17}$ Obviously, Fletcher's advocacy didn't always have lasting effects: the published praise she engineered from Cunningham didn't secure Godwin any enduring literary recognition, and Cunningham himself remains, at best, a minor player in the Scottish literary canon. Even so, Fletcher's correspondence demonstrates that in her own day, she both had and was willing to use a degree of literary influence that extended beyond the privacy of her own salon and into the world of print publication. Indeed, given Cunningham's relocation to London-and Fletcher's close friendships with London-based writers such as Anna Laetitia Barbauld-one could argue that that influence extended, however tenuously, well beyond Fletcher's Edinburgh base.

Yet even if one dismisses any larger claims about the geographic extent of Fletcher's influence, her literary friendships provide evidence that forms of coterie exchange remained an aspect of Edinburgh's literary society into the nineteenth century. That remains true despite the fact that some of the influential members of the city's emergent print culture were less than unequivocally welcoming to the ambitions of literary women who attempted to make a place for themselves through sociable exchanges. When Fletcher and Francis Jeffrey first met in the 1790s, Jeffrey referred scathingly to her and her friend Robina Millar

17. Eliza Fletcher, unpublished letter to Alan Cunningham 15 March 1835, Edinburgh: National Library of Scotland MS 2617 , ff. 77-78. Since an article describing Godwin as "one of the brightest stars in the constellation" of female poets appeared fewer than three weeks after the date of the letter, it seems that Cunningham was willing to oblige. 
as "women that would plague him with rational conversation"-a dismissal that apparently rankled enough for Fletcher to recall and record it many years later and many years into what was by then a cordial friendship with Jeffrey. ${ }^{18}$ Perhaps worse, literary hostesses could be dismissed merely as attractive accessories to an evening's talk. That seems to have been the fate of Jane Apreece, a wealthy widow with literary and scientific interests who (according to Sir Walter Scott) managed to use her charm to "establish[] herself as a leader of literary fashion" despite her lack of any natural "good taste either for science or letters." ${ }^{19}$ Yet despite such condescension or dismissiveness, other accounts make clear that Edinburgh remained in practice, if not always in perception, a literary society that was built upon the sort of mixed coterie exchange that Fletcher pursued throughout her career. Notwithstanding Jeffrey's dismissal of the idea of salon culture in general and-at least early on-of Fletcher in particular, Edinburgh literary women appear to have been regular participants in sociable but serious literary and intellectual debates, whether as guests or hosts. In 1811, for example, the medical student and traveller Henry Holland described a dinner party hosted by some women friends where he was "kept steadily at [...] work" throughout the evening, providing information on the landscape and culture of Iceland for his hostesses and fellow guests including Francis Jeffrey, Fletcher, and the novelist Elizabeth Hamilton. ${ }^{20}$ Granted, Holland's emphasis here is on his own conversational powers, in which he appears to take unselfconscious pride, but it is still worth noting that he singles out two literary women, along with Jeffrey, to convey the sophisticated nature of the audience that he was able to inform and entertain.

Yet it is not just the mixed nature of the informal literary networks of early nineteenth-century Edinburgh that make them noteworthy. Perhaps even more interesting, those networks did not merely co-exist with a culture of print publication but actually saw many of the same people at the forefront in both modes of literary work. However much the sort of disinterested corporate voice claimed by the literary maga-

18. Richardson, 279.

19. Quoted in Sophie Forgan, "Davy, Jane Lady Davy (1780-1855)," Oxford Dictionary of National Biography, Oxford University Press, 2004; online edition.

20. Henry Holland, unpublished letter to Peter Holland, 24 June 1811, Edinburgh: National Library of Scotland, ACC 7515 , f.2 
zines might initially seem to be at odds with the social intimacies through which Fletcher helped the literary careers of Cunningham and others, they are in fact thoroughly intertwined, with Jeffrey and the Edinburgh Review being prime examples of this interconnection. Despite his published scepticism about literary sociability, Jeffrey was in fact a remarkably sociable figure himself, and that social life was inextricable from his literary work. If one judges by correspondence covering the years of his editorship of The Edinburgh Review, almost every literary-minded visitor to Edinburgh sought the opportunity to meet and debate with him, and while in part that interest is a manifestation of an early form of celebrity culture-like Fletcher, Jeffrey was very much a sought-after literary celebrity in his day-there appears to have been an element of salon-like literary performativity in those conversations. Jeffrey was also quite willing to participate in versions of coterie authorship: in the 1790s, he debated women's literary achievements in a quasi-private exchange of verses with a female cousin and a young woman friend, ${ }^{21}$ and as late as 1810 he sent the manuscript version of his article on salons to Jane Apreece, rather audaciously soliciting her comments on and criticism of it. Granted, sending that particular manuscript to Apreece is decidedly double-edged, as Jeffrey's soliciting the opinion of a would-be salonière on his arguments about why such a role cannot exist in their society can be read as easily as a subtle insult as a compliment. Even so, paying attention to this sort of exchange complicates our understanding of what constituted literary work not just for women like Fletcher but also for Jeffrey, a figure at the epicentre of the new literary professionalism analysed by Siskin, Duncan and others.

The rediscovery or re-evaluation of the literary work of neglected or forgotten women, as important as that might be, is thus not the only reason to emphasize the continuing impact of social authorship in Edinburgh in the decades around 1800 . More generally, doing so highlights the difficulty of making any clean, clear division between Scotland's worlds of professional, print authorship and older modes of scribal or salon exchange, not only at the individual but also at the

21. The friend was Mary Grant (the eldest daughter of Anne Grant), then in her mid-teens; the poems were shared with and transcribed into a manuscript poetry album assembled by Jeffrey's cousin Margaret Loudon and now owned by the National Library of Scotland,MS 23,226. 
institutional level, and even at the moment that modern concepts of professionalism were becoming established. Indeed, some of the most influential new print media of the period evoked or imitated traditional forms of literary sociability. To take perhaps the most obvious example, Blackwood's Magazine's long-running and very popular Noctes Ambrosianae column is supposedly a transcription of the conversation of Blackwood's contributors during their sociable evenings at a tavern. On one level, of course, this sort of fictionalized sociability merely echoes the practice of earlier periodicals: the eponymous observers of The Spectator, The Idler, or The Lounger also tacitly invite readers to engage imaginatively with the social worlds they describe. Yet the Noctes columns go further in giving the reader a sense of being part of a knowing in-crowd, as part of the comedy derives from the interplay between the public personae of the writers and the quasi-fictional versions of themselves they construct for the magazine. Recognizing the real individuals and social relationships behind jokey pseudonyms allows readers to imagine themselves as something more than mere passive consumers of the printed word; in effect, what Blackwood's was doing was fostering the illusion that the anonymous, solitary reader was a knowing participant in, even if not an active contributor to, a version of private literary conversation reproduced in a very public medium.

This sort of pleasure was fostered by the rather stylized, performative aspects of "anonymous" publication in world of the Edinburgh magazines. As Karl Miller demonstrated decades ago, not only did the small and intimate social world of the early nineteenth-century Edinburgh literati ensure that the ostensibly undifferentiated "we" of the literary magazines was more a pose than a fact, but also that that pose functioned, to some extent, as a part of a sophisticated literary game. "The pleasures of anonymity," Miller notes drily, "would have been sadly diminished if it had spoilt the opportunity of building a reputation." 22 The significant point for this argument is that those pleasures were not simply those of the writer, who was able to wrap himself in the public authority of the magazine while simultaneously claiming private recognition and-ideally-admiration for his work. Just as importantly, the magazines' more or less sketchily maintained

22. Karl Miller, Doubles: Studies in Literary History (Oxford: Oxford UP, 1985), 112 . 
anonymity offered an added pleasure to readers: those who guessed, or were informed of, the authorship of an anonymously published article were, yet again, given the illusion of being something more than passive consumers of the printed word. The article itself might have absolutely nothing to do with the private life or attitudes of the individual who wrote it, but even so, the act of breaking through anonymity, in itself, gave readers access to an implicitly less public, more sociable engagement with that work.

Granted, the pleasures of breaking through a deliberately flimsy literary veil were not limited to the readers of Edinburgh's early nineteenth-century periodicals: the thrill of gaining quasi-insider knowledge was also part of the appeal of genres such as the roman à clef or (earlier) the secret history. What makes those periodicals particularly noteworthy is how very narrow the dividing line could be between writers' "professional" and "social" modes of literary conversation, something just as true of the Edinburgh Review as of Blackwood's. Even if the idea of sociable exchange shaping the form of a print production isn't as immediately obvious in the case of The Edinburgh Review as it is in the Noctes Ambrosianae, the sociable underpinnings of the earlier journal remain striking, not least because its anonymous articles and its audaciously confident pose of disembodied cultural authority might appear to be very far removed indeed from the sort of sociable exchange of ideas valorized by literary conversation or manuscript exchange.

Indeed, the degree to which, at least during its early years, the public, professional world of The Edinburgh Review maintained links with certain modes of scribal authorship can be striking. There is evidence that a number of readers saw Edinburgh Review articles as part of a conversation that could take place both in print and in person, making the magazine, in effect, a contributor to literary sociability, rather than a retreat from it. The most famous example of this sort of quasi-social back-and-forth is perhaps Jeffrey's encounter with James Madison and James Monroe, in which the American President and Secretary of State used Edinburgh Review articles about the War of 1812, then still in progress, as the starting point of a private debate with Jeffrey about national policy and national loyalties. Rather more prosaically, the English medical student Henry Holland makes clear in correspondence with his father that reviewers' identities "speedily become known" in Edinburgh, and that as a result "the articles are taken up 
for criticism $\&$ canvass [...] in the name of the ascertained writer." ${ }^{23}$ Intriguingly, he also suggests that such "criticism and canvassing" frequently took place with the authors themselves, before the articles were published as well as after. It is Holland who reports that Jane Apreece criticised Jeffrey's article on the salons while it was still in manuscript; likewise, he implies, perhaps a little boastfully, that published comments on Sir Humphry Davy by the mathematician John Leslie were honed in detailed conversations that Leslie and Holland had had on the subject. A few months later, Holland was reporting a less happy exchange between Jeffrey and Elizabeth Hamilton about Lucy Aikin. According to Holland, Hamilton believed that she had talked Jeffrey out of moving from conversation to print in his negative assessment of Aikin's work, and then made no secret of her disappointment when she found out otherwise. In the minds of both Hamilton and Holland-at least if one can trust Holland's report of the incident-Jeffrey's anonymous and very public critique of Aikin's work functions as just one element in a multifaceted and ongoing debate among members of a literary community.

On one level, of course, Holland's account of his insider perspective on The Edinburgh Review is little more than literary gossip. Yet even allowing for an element of gossipy pleasure in being able to present himself to his father as part of an "in" crowd, the letters still suggest that Holland saw the social and the professional as being entirely continuous. Reporting on a dinner party hosted by Macvey Napier and attended by Jeffrey, Leslie, and John Playfair, among others, Holland comments that it was a "particularly pleasant" evening, marked by conversation of "great spirit \& vivacity," as one would expect from a "groupe of Reviewers." The most striking aspect of this observation is not so much the glimpse of the Edinburgh reviewers' private friendships with each other or Holland's rather naïve assumption that critics will naturally also be entertaining conversationalists. Rather, what Holland seems to find-and expects to find-in this and other gatherings of a similar nature is both a continuation and an extension of the sort

23. Henry Holland, unpublished letter to Peter Holland, 4 March 1810, Edinburgh: National Library of Scotland, ACC 7515; the comments on Leslie are in the same letter, while both the comments on Hamilton and Aikin and on the "vivacity" of the Edinburgh reviewers (quoted in the next paragraph) appear in a letter dated 17 March 1811. 
of intellectual battles carried out in the pages of the Edinburgh. Private conversation not only influences published writing-as Holland implies in the case of his and Leslie's discussions about Davy-but, more significantly, continues and mirrors the forceful expression of opinion in the printed work. This perspective is not something that appears only in Holland's letters either; other observers of the Edinburgh scene had a similar view. Shortly after settling in Edinburgh in 1808, Anne Grant commented on the "spirit and intelligence" of the conversation at Edinburgh social gatherings, describing it in terms that make it sound very much like an oral version of an Edinburgh Review article: "There are syllogisms and epigrams, and now and then, pointed and brilliant sentences, and observations, and reflections both acute and profound [...] there is much intelligence, and a degree of metaphysical subtilty in argument and disquisition." ${ }^{24}$ Even if Grant is not entirely approving in her account of these conversations (she also claims that they lack "heart"), the point remains that she is describing a world in which the division between private sociability and public authorship is productively blurred.

In effect, the world that Grant and Holland were describing was one in which private literary networks shaped in complicated and fundamental ways the new print culture of Edinburgh. Other contemporary observers suggest much the same thing; a few years later, Elizabeth Isabella Spence made a similar point about what she saw as the characteristically Scottish literary sociability when she commented on the "constellation of Scottish genius" on display in social gatherings. ${ }^{25}$ Admittedly, Spence was using the metaphor in the context of her praise of the novelist Henry Mackenzie and thus in part to refer to the generation of scholars and writers who had been his contemporaries in the last quarter of the eighteenth century. Yet the image also conveys her sense of the continuing importance of literary networks in Edinburgh into the second decade of the nineteenth. Spence presents Mackenzie not just as the only remaining luminary of an older, vanished generation, but also as one of the brightest lights of the presentday circle made up of the "successors of those stars now set." 26 The

24. J[ohn] P[eter] Grant, (ed.), Memoir and Correspondence of Mrs. Grant of Laggan. 3 vols. (London: Longman, 1845), 1: 240-41.

25. Spence, 285.

26. Spence, 36. 
implication of the image is, first, that Spence sees no significant shift in the literary practice of the two generations, despite the many developments in the publishing industry over that period. Second, and more importantly, she presents Edinburgh literary culture of both the past and the present as a group production: after all, even if some points in a constellation are brighter than others, all are necessary to make up the pattern. In her use of this metaphor, Spence thus quietly calls our attention to the continuing importance of sociable networks in understanding the cultural life of Edinburgh at the dawn of the era of literary professionalism. 